\title{
KASITSIZ HAKARET (MICROAGGRESSIONS) VE TÜRKIYE'DE SIK GÖRÜLEN ÖRNEKLERİ
}

\section{İsmail GÜLEÇ * Erkan ÖZDEN**}

\section{Öz}

Bu çalışmanın amacı Türkiye'deki yabancı uyruklu bireylerin "mikroagresyonlar"a (microaggressions) ilişkin tecrübelerini ve sorunlarını ortaya çıkarmaktır. Bu bağlamda Türkiye'ye eğitim, daha iyi bir hayat için göç ya da savaştan kaçış gibi değişik sebeplerle gelen bu bireylerin mikroagresyonların değişik çeşitlerinden hangilerine ne sıklıkla maruz kaldıkları belirlenmeye çalışılmıştır. Araştırma beş farklı ilde yapılan görüşmelerle gerçekleştirilmiştir. İlkokuldan üniversiteye kadar eğitimin her kademesinden öğrenci, öğretmen, öğrenci velileri ve doktorlar ile görüşülmüştür. Verileri toplamak için katılımcılara "Türkiye'de sizin kültürünüze ve etnik farklılığınıza yönelik kasıtlı ya da kasıtsız kırıcı, incitici söz ve davranışlara maruz kalıyor musunuz?” sorusu yöneltilmiştir. Çalışmanın sonuçları mikroagresyonların ülkemizde çok ciddi bir sorun olduğunu göstermektedir. Araştırmaya göre vatandaşlarımız yabancılara karşı çok anlayışlı değildir ve yabancı uyruklu kimselere kendilerini ikinci sınıf vatandaş gibi ve dışlanmış hissettirecek davranışlar çok yoğundur. Yabancılara olumsuz şeyler yakıştırılmakta, burada istenmedikleri sezdirilmekte hatta ülkemizdeki birçok sıkıntının nedeni olmakla itham edilmektedirler. Ayrıca araștırmanın bulguları yabancı uyruklu kişilerin kültürleri ile ilgili önyargılardan muzdarip oldukları ve özellikle ırkla ilgili açık, doğrudan hakaretlere de yoğunlukla hedef oldukları yönündedir.

Anahtar Kelimeler: Toplum, Yabancı Uyruklu, Göçmen, Mikroagresyon, Kasıtsız Hakaret

\footnotetext{
* Prof. Dr., İstanbul Medeniyet Üniversitesi, ismail.gulec@medeniyet.edu.tr, ORCID: 0000-0002-0174-148X

** Öğr. Gör., Sakarya Üniversitesi, eozden@sakarya.edu.tr, ORCID: 0000-0003-18375831
} 


\title{
Unintentional Insult (Microaggressions) and Its Common Examples in Turkey
}

\begin{abstract}
This study aims to investigate the experiences and problems of foreign nationals in Turkey, concerning microaggressions. Thus, it was aimed to find out which types of microaggressions -and at what frequency- are experienced by people who come to Turkey for different reasons like education, pursuit of a better life or escaping from war. The study was conducted in five different cities of Turkey. Students from primary school to university, teachers, parents and doctors took part in the study. The participants were asked the single question "Do you ever experience deliberate or undeliberate insults, whether verbal or behavioral, targeting your ethnic identity and diversity in Turkey?" The results of the study show that microaggression is a very serious problem in Turkey. It can be gathered from the findings that Turkish people are not as tolerant to foreign people as they used to be. Behaviors that make people of foreign origin feel like second-class citizens and alienated take place quite often. Foreigners are usually connected with negative occurrences and they are reminded that they are not welcome in this country. These people are also accused of causing many misfortunes in the country. The study also exhibits that foreign nationals suffer greatly from prejudices about their cultures and they become the target of explicit and direct insults particularly regarding their race.
\end{abstract}

Keywords: Society, Foreign National, Immigrant, Microaggression, Unintentional Insult

\section{Giriş}

Son on yılda dünyadaki ve ülkemizdeki gelişmeler Türkiye’yi cazibe merkezi haline getirmiş ve bunun sonucunda farklı amaç ve nedenlerden dolayı yabancıların ülkemize geldikleri görülmeye başlanmıştır. Özellikle Yurtdışı Türkler ve Akraba Topluluklar Başkanlığı'nın (YTB) 2012 yılında başlattığı uygulama ile dünyanın dört bir tarafından yabancı öğrenciler ülkemize gelmeye başlamış, nüfusça küçük illerimizdeki üniversitelerimiz bile yabancı öğrencilerle tanışmaya başlamıştır. YTB her yıl ortalama 4000-5000 
civarında yabancı öğrenciye Türkiye bursu vermektedir ancak başvuran sayısı bunun kat ve kat üzerindedir. Aşağıdaki tabloda YTB bursu için yapılan başvuruların yıllar içerisindeki artışı görülmektedir.

\section{Tablo 1. Yıllara Göre YTB Bursuna Başvuran Yabancı Öğrenci Sayıları}

\begin{tabular}{|c|c|}
\hline Yll & Başvuran öğrenci sayısı \\
\hline 2012 & 42000 \\
\hline 2013 & 56000 \\
\hline 2014 & 82000 \\
\hline 2015 & 114000 \\
\hline 2016 & 120000 \\
\hline 2017 & 106550 \\
\hline 2018 & 135000 \\
\hline 2019 & 172000 \\
\hline
\end{tabular}

Kaynak: YTB, 2019

YTB burslusu öğrencilerin ülkelerindeki olumlu tanıtımları diğer öğrencilerin de yüksek öğrenimde Türkiye'yi düşünmelerini sağlamıştır. Burslu olarak gelen yabancı öğrencilerin ardından üniversiteler yabancı öğrenci alabilmek için YÖS sınavları başlatmışlar ve yabancı öğrenci sayısını artırmanın yollarını aramaya başlamışlardır. Geçtiğimiz beş eğitim-öğretim döneminde Türkiye'deki üniversitelerin toplam yabancı öğrenci sayıları aşağıdaki gibidir.

Tablo 2. Yıllara Göre Türkiye'deki Yabancı Üniversite Öğrencisi Sayıları

\begin{tabular}{|c|c|}
\hline Yıl & Yabancı Öğrenci Sayısı \\
\hline $2013-2014$ & 41641 \\
\hline $2014-2015$ & 61181 \\
\hline $2015-2016$ & 74441 \\
\hline $2016-2017$ & 98639 \\
\hline $2017-2018$ & 114798 \\
\hline
\end{tabular}

Kaynak: YÖK, 2019 
Görüldüğü gibi Türkiye, memleketinin dışında eğitim görmek isteyenler arasında gittikçe daha popüler bir tercih olmaktadır. Üniversitelerimizde her yıl sayısı katlanarak artan yabancı öğrencilerimiz bunun en iyi göstergesidir. Farklı bir kültür ortamında eğitim gören bu öğrencilerin yaşadığı çok çeşitli sıkıntılar olması da kaçınılmazdır. Alan yazında bunlarla ilgili birçok çalışma vardır. Güleç \& İnce'nin (2013) Sakarya Üniversitesi TÖMER'de eğitim gören yabancı öğrencilerin Türk kültürüne uyum sorunlarını inceledikleri; Garabayev'in (2000) Türk üniversitelerinde eğitim gören Türk Cumhuriyetleri öğrencilerinin uyum sorunlarını araștırdıkları, Kıroğlu vd. (2010) Türkiye'de öğrenim gören yabancı uyruklu lisans öğrencilerinin sosyo-kültürel ve ekonomik sorunları üzerine yaptıkları araştırmalar konu ile ilgili yapılan çalışmalardan sadece birkaçıdır. $\mathrm{Bu}$ çalışmalara katılan öğrencilerde "maddi zorluklar, memleket hasreti, yemek kültürüne yabancılık" gibi bulgulara rastlanmıştır.

Yabancıların ülkemize gelmesinin tek sebebi eğitim değildir. Ülkemizin içinde bulunduğu coğrafyadaki siyasi istikrarsızlık ve iç savaşlar göçleri hızlandırmış, her yaştan ve her kesimden yabancıların ülkemize gelmelerine neden olmuştur. 2000’lerin başında Irak savaşı ile başlayan göçler, 2010'larda Suriye ile devam etmiş, daha sonraki yıllarda da Yemen ve Afganistan ile devam etmiştir.

Üçüncü bir grupta ise daha iyi yaşam sürmek ve ailesini geçindirmek için Ermenistan, Gürcistan gibi komşu ülkeler ile Afrika ülkelerinin vatandaşlarının gelmesiyle farklı bir göç dalgası oluşmuştur.

Hiç şüphesiz eğitim, savaştan kaçış ve daha iyi bir yaşam için bu kadar farklı ülkelerden ve kültürlerden gelen yabancı insanı ağırlayan bir ülkede bu insanlara karşı kimi olumsuz tutum ve davranışların olması kaçınılmazdır. Örneğin yeni bir topluma dâhil olan bu insanlar kültürel uyumda ve işleyişi öğrenmekte zorlanmaktayken umdukları yardımı her zaman görememektedirler. Maalesef değişik biçimlerde 
bu ülkede hoş karşılanmadıkları da hissettirilmektedir. Yöresel kıyafetlerini giyenler ya da ana dillerini konuşanlar rahatsız edici bakışlarla, hatta bazen sözlü olarak taciz edilebilmektedir. Rusya'dan gelenlerin hepsini Rus zannetmek, Arap kökenlilerin hepsinin ailesinde çok eşliliğin olduğunu ve elle yemek yediklerini düşünmek gibi önyargılar da yabancılara sorun çıkarabilmektedir.

Yabancllara karşı gösterilen düşmanca ve ırkçı tutum ve davranışların yanı sıra kimi insanlarda açık olmayan ama onları dışlayan ve aşağllayan davranışlar da görülmektedir.

\section{2. "Microaggression" nedir? Kavram ve Muhteva}

Yabancılara karşı doğrudan ırkçı ve dışlayıcı saldırıların yanı sıra muhatabına karşı bir taciz ve hakaret amacı gütmeksizin, farkında olmadan muhatabını üzen kimi davranışlar da gösterilmekte, çoğu kere davranış sahibi muhatabının incinmiş olabileceğini düşünmemekte ve farkına varamamaktadır. Merriam-Webster (2018) bu durumu "toplumun genelinden farklı bir grubun bireylerini genelde kasıtsız, farkında bile olmadan, önyargılı bir şekilde incitecek söz ya da davranışlara" 'microaggressions' denmektedir" şeklinde gayet net bir şekilde tarif etmektedir. Ancak kavramın sözlüğe girmesi çok eski yıllara dayanmamaktadır. Çokça başvurulan İngilizce sözlük Merriam-Webster kavramın sözlüğe ilk kez girişini 1970 olarak göstermektedir çünkü "aggression" terimi "micro" öneki ile ilk kez 1970 yllında Universitas isimli bir dergideki "Reports on Crimes of Aggression" başlıklı makalede kullanılmıştır. Çalışmanın sahibi W. Hallermann'dır (Merriam-Webster Online Dictionary, 2019).

Ancak "microaggression" kavramını aynı yıl içerisinde, birkaç ay sonra farklı bir çalışmada kullanan Dr. Chester Pierce kavramı literatüre kazandıran kişi olarak kabul görmüştür. Kendisi Harvard Medical School'a kabul edilen ilk Afro-Amerikan psikiyatrist olan Pierce'ın siyah ve psikiyatrist olmasının konu üzerine dikkatini çekmesinde katkısı olduğu düşünülebilir. Pierce'ın yaptığı 
çalışmalarda amacı toplumda farklı ırklar arasındaki uzlaşı eksikliğine dikkat çekmekti (Wells, 2017). Beyaz insanlardan siyahilere yöneltilen küçük ve devamlı mikroagresyonlardan saldırı mekanizmaları (psikolojideki savunma mekanizmaları kavramının zıttı anlamında) olarak bahsetmiş ve bunların ırklar arası etkileşimin temel muhtevası olduğunun altını çizmiştir (Pierce, 1970). Mikroagresyonları "üstü kapalı (örtük) ve sersemletici saldırgan ifadeler" (Pierce, 1970, 266) olarak tanımlamış ve böyle tek bir ifadenin zararsız görünebileceğini ancak bunun devaml yapılması durumunda muhatabında tahayyül edilemeyecek derecede ağır bir etki yapabileceğini belirtmiştir. Pierce'ın siyah-beyaz ilişkilerinden yola çıkarak ortaya koyduğu tanım daha sonra tüm farklı gruplar üzerinde uygulanacak ve aranacaktır.

Pierce'dan sonra bu konuyla en çok ilgilenen ve günümüzde de halen çalışmaları bulunan Sue vd. de birey üzerinde kötü bir etki bırakan bu tarz ifadelerin sadece etnik azınlık grupları arasında gerçekleşmediğini, aynı zamanda farklı cinsiyet ya da cinsel tercihe mensup veya engellilik özelliği taşıyan bireylere karşı da gerçekleşebildiğinin üzerinde durmuşlar (Sue vd., 2007, 284) ve ırkçı mikroagresyonları "ırka dayalı bir azınlık grubuna dâhil oldukları için farklı renge sahip insanlara yöneltilen ve aşağılayıcı mesaj içeren kısa, her gün rastlanabilen ifadeler (Sue vd., 2007, 273)" olarak tanımlamışlardır. Pierce'ın tanımı gibi ırk meselesine eğilmiş olmakla beraber bu tanım sadece siyahileri değil tüm etnik azınlıkları kapsamaya başlamıştır.

Sue ve arkadaşları araştırmaları sonucu ırkçı "mikroagresyonları (microaggressions)" üç alt başlık altında incelemişlerdir.

Microassault (mikro-saldırı): Sue ve ekibine göre bu "eski moda” ırkçılığa en çok benzeyen türdür ve genellikle kasıtlı olan, sözlü/sözlü olmayan saldırıları anlatmaktadır. İnsanları görmezden gelmek, lakap takmak, siyahi bireylerin de olduğu ortamlarda beyaz müşterilere önce hizmet vermek bunun örneklerindendir. 
Microinsult (mikro-hakaret): Bunlar bir insanın ırkına ve kimliğine yönelik kaba ve duyarsız ifadelerdir. Genellikle bilinçsiz yapılmakla birlikte muhataplarını çok incitirler. Beyaz bir işverenin "Bence insanlar işe alınırken milliyetlerine değil yeteneklerine bakılmalı" demesi ya da beyaz bir amirin siyahi bir çalışanla konuşurken rahatsız bir tutum sergilemesi, gözünü kaçırması gibi davranışlar da bu gruba girer (Hinton, 2004'ten akt. Sue vd., 2007). Hepsinin ortak özelliği o kişiye kendini kıymetsiz hissettirmesidir.

Microinvalidation (mikro-değersizleștirme): Farklı milliyete sahip bireylerin düşünceleri, duyguları ve tecrübelerini yok sayan, geçersiz kılan her çeşit ifade bu türdedir. Örneğin Amerika'da doğup büyüdüğ̈ halde Asya kökenli birisine İngilizcesinin çok iyi olduğunu söylemek onların Amerikan kimliğini reddetmektir. "Hepimiz insanız", "Hepimiz kardeşiz" (Helms, 1992'den akt. Sue vd., 2007) ya da "Fazla abartıyorsun, alınganlık yapıyorsun" tarzı ifadeler de bu kapsamdadır.

Dr. Chester Pierce "mikroagresyonları" sadece siyah-beyaz çatışmasına dayandırdığı için belki de bu yüzden bugün hala mikroagresyonlar sadece bir ırk meselesi sanılabilir ve tanımındaki "toplumun genelinden farklı gruplar" ifadesinden sadece farklı milliyetler anlaşılabilir ancak özünde mikroagresyonlar milliyet, göçmenlik, cinsiyet, cinsel tercih, engellilik ve daha birçok açıdan kendini göstermektedir.

Yakın zamana gelindiğinde konuyla ilgili çalışmaların sayısının artmaya başladığı görülmektedir. Örneğin Shenoy-Packer (2015)'ın Amerika'da çalışan göçmenler ile ilgili araştırması bu insanların her gün maruz kaldıkları mikroagresyonları gözler önüne sermektedir. Araştırmaya katılan bireyler etnik kökenlerinden kaynaklanan ve bazen sözlü bazen tutumsal mikroagresyonlarla karşı karşıya kalmaktadırlar. Değişik aksanlarını fark edenler "Nereden geldin?", "Ne kadar zamandır buradasın?" diye sormaktadır. "Esmer değilsin, nasıl Meksikalısın?" ya da "Asyalısın, çok zeki olmalısın" gibi 
basmakalıp temelli söylemlere de işyerlerinde sıkça rastlanmaktadır.

Bir diğer yabancı kaynaklı araştırma da 2018 yılında Bonifacio vd. tarafından yapılmıștır. The Counseling Psychologist isimli dergide yayınladıkları "Microaggressions and Ethnic Identity in the Career Development of Latina College Students (Latin Kökenli Üniversite Öğrencilerinin Kariyer Gelişimlerinde Mikroagresyon ve Etnik Kimlik" başlıklı çalışmalarında 202 Latin kökenli öğrenci ile yaptıkları araştırmaya yer vermişlerdir. İlgili araştırmada etnik kimlik ve mikroagresyonlarla ilgili tecrübelerin bu öğrencilerin kariyer planlamaları açısından öz yeterliliklerini nasıl etkilediği incelenmiş ve mikroagresyonlara daha fazla maruz kalmış olan öğrencilerin kendileri ile ilgili kariyer beklentilerinin düştüğü belirlenmiştir.

Mikroagresyonlar hakkında yapılmış en yakın zamanlı ve kapsamlı araştırmalardan biri de Lilly vd. (2018) aittir. Lilly vd. yayınladıkları "The Influence of Racial Microaggressions and Social Rank on Risk for Depression among Minority Graduate and Professional Students (Irkçı Mikroagresyonların ve Sosyal Statünün Azınlık Üniversite Öğrencilerinde Depresyon Riski Üzerine Etkileri (Lilly vd., 2018)" isimli çalışmalarında 325 tane azınlık grubu üniversite öğrencisinin katılımı ile gerçekleştirdikleri geniş bir araştırmaya yer vermişlerdir. Bu öğrencilere hem mikroagresyonlara ne kadar maruz kaldıkları ile ilgili hem de depresyonla ilgili anket soruları yöneltilmiştir. $\mathrm{Bu}$ şekilde mikroagresyonlar ile azınlık durumundaki üniversite öğrencilerinde depresyon riski arasında anlamlı bir ilişki olup olmadığı belirlenmeye çalışılmıştır. Sonuçlara bakıldığında ise öğrencilerin \%98.8'inin yakın zamanda mikroagresyona maruz kaldığı ve ayrıca bu öğrencilerin depresyona girme riskinin 2.14 kat daha fazla olduğu görülmüştür.

Yerli kaynaklara bakıldı̆̆ında ise konuyla ilgili çok fazla çalışmaya rastlanmamaktadır. Örneğin Çınarbaş vd. 2012'de yayınladıkları “Engelli mi Engellenen mi? Türkiye'de Engellilerin 
Karşılaştıkları Ayrımcı Tavır ve Davranışlar” isimli çalışmalarında Sue vd. (2007) mikroagresyonlar modelini temel alarak engelli bireylerin yaşadıkları sorunları araştırmışlardır. Her ne kadar araştırmada hedeflenen "ırka dayalı mikroagresyon" konusuyla tam örtüşmese de mikroagresyon kavramıyla ilgili olduğu için burada bahsetmeye uygun görülmüştür. Çınarbaş vd. on iki engelli bireyle yürüttükleri çalışma sonucunda "kişiliğin yadsınması," "deneyimlerin yadsınması," "acizlik," "bir konudaki engelin diğer alanlara da sirayet etmesi," ve "ikinci sınıf vatandaş" gibi temalara ulaşmışlardır.

Türkçe kaynaklar içerisinde doğrudan ırkçı mikroagresyon ile ilgili ulaşılabilen sayılı araştırmalardan biri Mehmet Er (2018)'in "Yabancı Dil Olarak Türkçe Öğretiminde Mikroagresyon" isimli çalışmasıdır. Er, Gazi Üniversitesi TÖMER'de 2017-2018 eğitimöğretim döneminde öğrenim gören yabancı uyruklu on iki yüksek öğrenim öğrencisi ile gerçekleştirdiği araştırmasında Yabancı dil olarak Türkçe öğretiminde mikro agresif tutumların yani "örtükincitici tavırlar"ın sebeplerini bulmaya çalışmıştır. Araştırmanın sonuçlarına göre:

- Öğrencilerin hiçbiri Türkiye'ye geldikten sonra ötekileştirici bir tavırla karşılaşmamıştır.

- Öğrencilerin hiçbiri öğretmenleri tarafından da dışlanmamıştır.

- Yalnızca bir Suriyeli öğrenci (\%8) ülkesi ile ilgili olarak ayrımcı bir tavra maruz kalmıştır.

- Öğrenciler devlet birimlerinde bazen olumsuz tavirlarla karşılaşmaktadırlar.

- Bunun dışında cinsiyet, yaş, ülke, eğitim durumu gibi demografik özelliklere bakılarak, verilen cevaplarda anlamlı bir farklılık görülmemiştir. 
İkinci bir çalışma Ünal (2018) tarafından yapılmıştır. "Irksal Temelli Ayrımcılığın Yeni Görünmez Yüzü: Kültürel Karşılaşmalar ve Mikro-Saldırganlıklar" başlıklı çalışmada Ünal "microaggression" kavramı ile ilgili başlıca yabancı kaynaklara başvurarak bu kavramı tanımlamış ve açıklamıştır. Eski tip ve açıktan yapılan ırkçılığın yerini daha üstü kapalı, ince saldırılara yani "mikro-saldırganlıklar"a bıraktığına dikkat çeken yazar bu çalışma ile daha sonra yapılabilecek başka çalışmalara teorik ve kavramsal bir şema sunmayı amaçlamıştır.

"Microggression" ile ilgili ulaşılabilen bir diğer Türkçe çalışma da "Kültürlerin Temas Alanı Olarak Dil Öğretimi Süreçleri Ve Mikro Saldırganlıklar" (Durmuş, 2019) dır. Durmuş da bu çalışmada yabancı kaynaklara başvurarak "microaggression" konusunu özetlemiş, alana kazandırmaya çalışmıştır. Yazar kültürlerin karşılaşma alanlarının hepsinde olduğu gibi dil öğretim ortamlarında da mikro saldırganlıkların sebep olabileceği potansiyel tehlikelere dikkat çekmiş ve çözüm önerilerinde bulunmuştur.

Görüldügü gibi Türkiye'de yayınlanan çalışmaların azlığı meselenin daha da derinlemesine incelenmesi gerekliliğini göstermektedir.

\section{3. Örtük Saldırı mı? Kasıtsız Hakaret mi?}

Çok yeni bir kavram olan mikroagresyonun Türkçeye ne şekilde aktarlacağı konusunda henüz üzerinde ittifak edilmiş bir kelime bulunmamaktadır. Webster'daki (2018) tanıma göre mikroagresyon olabilmesi için mutlaka farklı cins, kesim, inanç, milliyet veya farklı bir aidiyet grubuna mensup iki kişinin olması, bunlardan birinin yerleşik ve güçlü, diğerinin ise sonradan gelmiş ve zayıf olması durumu söz konusudur. Güçlü ve yerleşik olanın yeni ve zayıf olanı üzmek ve hakaret etmek kastı gütmeksizin incitici ve kırıcı sözler söylemesi ve davranışlar göstermesi gerekir. Pierce'nin “üstü kapalı, örtük saldırgan ifade" olarak nitelediği bu kavramı Türkçede "kasıtsız hakaret" olarak ifade edebiliriz. Muhatabın hakaret ve kırıcı bulduğu 
söz ve davranışların sahibine bakıldığında yaptığının veya söylediğinin çok normal olduğunu, hakaret etmediğini bilakis övdügünü söylediğine şahit olunmaktadır. $\mathrm{Bu}$ yüzden bizce mikroagresyonu karşılayan en uygun ifade "kasıtsız hakaret"tir. Çalışmanın bundan sonraki kısmında bu ifade kullanılacaktır. Saldırı kelimesini şiddet ve kastı yoğun şekilde akla getirdiği için kullanmaktan sakındık. Çünkü saldırı sözlü ve fiili olarak olmakta ve söylenildiğinde fiili olanı da çağrıştırmaktadır. Oysa hakarette fiilden çok söz akla gelmektedir.

\section{Araştırmalarda Verilen Kasıtsız Hakaret Örnekleri}

Konunun daha açık ve net anlaşılması için yapılan çalışmalarda görülen birkaç çarpıcı örneği paylaşmak istiyoruz.

2010'lardan sonra bir gençlik hareketi olarak bir tepki doğmuş ve üniversite kampüsleri konu ile ilgili hareketlenmiştir. Amerika'da bir sergi açılmış ve öğrenciler başlarından geçenleri fotoğraflar ile anlatmaya çalışmışlardır. Bu sergide Afrikalı-Amerikalı bir üniversite öğrencisinin "Siyah derili bir kıza göre çok güzelsin." pankartı (Nigatu, 2013). Bu cümle siyah derili kızların aslında güzel olmadıklarını ima etmektedir ve güzellik ölçüsünün tüm kızlar olmadığı, sadece siyahlar içinde değerlendirildiği görülmektedir. Kızın güzelliğini övdüğünü düşünen kişi aslında farkında olmadan kıza hakaret etmektedir.

Engelli bir bireye istemediği halde ısrarla yardım etmek. (Zukauskas, 2018) İyi niyetli olduğundan asla kuşku duyulmayan bu tür davranış engelli bireyin kendisini yetersiz hissetmesine neden olabileceği gibi karşısındakinin kendisini çok yetersiz ve acınacak bir durumda olarak algıladığını düşünmesine ve üzülmesine de yol açacaktır.

"Nerede doğdun?" sorusu çok masum görünmekle birlikte sorunun muhatabına "Aslında sen buraya ait değilsin" mesajını verebilir (Zukauskas, 2018). Bu soru her zaman kasitsız hakaret olarak 
değerlendirilmemeli, bazen tanışmak için de sorulduğu unutulmamalıdır.

Sokakta yürürken yaklaşan siyahi bir delikanlıyı karşıdan görür görmez çantanıza daha sıkı sarılmanız (McTernan, 2017). Muhatabının doğal suçlu olduğunu kabul eden bu davranış da önyargılı bir tutumdur.

Asya kökenli bir Amerikallya çok iyi İngilizce konuştuğunu söylemek. (McTernan, 2017) Bu cümlenin altında aslında Asya kökenli biri güzel İngilizce konuşamaz önyargısı yatmaktadır.

Görüldügü üzere kasıtsız hakaretler sadece ırkçı bir yaklaşımın ürünü değildir. Bu yüzden bu çalışmada görüşleri alınan bireylerin tecrübe ettikleri her türlü zorluk tespit edilmeye çalışılmıştır. Ancak katılımcıların farklı kültürden gelmiş olma ile ilgili maruz kaldıkları kasıtsız hakaretleri tespit etmeye yarayacak verilere ulaşabilmek özellikle amaçlanmıştır. Zira bu konuda önemli çalışmaları bulunan Derald Wing Sue ve arkadaşlarının yürüttükleri ortak çalışmalardan anlaşılmıştır ki "bireylerin devamlı olarak ırkçı kasıtsız hakaretlere maruz kalmaları özgüvenlerine alışılagelmiş ırkçılık çeşitlerinden daha fazla zarar vermektedir" (Sue vd., 2009; Sue vd., 2007'den akt. Bonifacio, 2018). Yani meselenin bu yönü ayrıca önem arz etmektedir.

Araştırmanın yöntem kısmına geçmeden önce Sue ve arkadaşlarının (2007) kasıtsız hakaretler ile ilgili yaptıkları araştırmalar sonucunda tespit ettikleri dokuz farklı ırkçı kasıtsız hakaret temasını örnekleri ve altlarında yatan gizli mesajları ile birlikte bir tabloda inceleyelim. Araştırmanın devamında kendi kasıtsız hakaret tanımımızın kapsamına giren örnekler üzerinden farklı bir tasnif tablosu yaplacaktır.

Tablo 3. Irkçı Kasıtsız Hakaretlere Örnekler

\begin{tabular}{|l|l|r|}
\hline Tema & Örnek & Altındaki mesaj \\
\hline Kendi & “Nerelisin?” “Nerede & Sen Amerikalı \\
\hline
\end{tabular}




\begin{tabular}{|c|c|c|}
\hline $\begin{array}{l}\text { ülkende } \\
\text { yabancı }\end{array}$ & doğdun? "İngilizcen çok iyi.” & değilsin, yabancısın. \\
\hline Zeki görme & $\begin{array}{l}\text { "Sen ne kadar da } \\
\text { başarılısın." }\end{array}$ & $\begin{array}{r}\text { Farklı renklerden } \\
\text { olanlar başarılı } \\
\text { olamazlar. }\end{array}$ \\
\hline $\begin{array}{l}\text { Renk } \\
\text { ayırmazlık }\end{array}$ & $\begin{array}{l}\text { "Hepimiz aslında tek } \\
\text { milletiz." "Amerika } \\
\text { farklılıkların aynı potada } \\
\text { eridiği bir yerdir." }\end{array}$ & $\begin{array}{l}\text { Senin farklılığını } \\
\text { kabul etmiyoruz. }\end{array}$ \\
\hline $\begin{array}{l}\text { Potansiyel } \\
\text { suçlu görme }\end{array}$ & $\begin{array}{l}\text { Yolda Latin kökenli birisine } \\
\text { rastlayan bir bayanın } \\
\text { çantasını sakınması. Market } \\
\text { sahibinin siyahi müşteriyi } \\
\text { reyonlar arasında daha sıkı } \\
\text { takip etmesi. }\end{array}$ & $\begin{array}{r}\text { Sen fakir, tehlikeli ve } \\
\text { suça meyillisin. }\end{array}$ \\
\hline $\begin{array}{l}\text { Irkçı } \\
\text { olduğunu } \\
\text { inkar etme }\end{array}$ & $\begin{array}{l}\text { "Ben ırkçı değilim." "Bir } \\
\text { sürü siyahi arkadaşım var." }\end{array}$ & $\begin{array}{r}\text { Irkçılığa karşı } \\
\text { bağışıklığım var } \\
\text { çünkü farklı } \\
\text { renklerden } \\
\text { arkadaşlarım var. }\end{array}$ \\
\hline $\begin{array}{l}\text { Hakkaniyetle } \\
\text { ilgili } \\
\text { söylentiler } \\
\end{array}$ & $\begin{array}{l}\text { "Bence en çok hak eden } \\
\text { kimse o işe alınmalı." }\end{array}$ & $\begin{array}{r}\text { Renkli insanlar } \\
\text { avantajlı durumdalar. }\end{array}$ \\
\hline $\begin{array}{l}\text { Kültürel } \\
\text { değerleri } \\
\text { așağllama }\end{array}$ & $\begin{array}{l}\text { Siyahi birisine "Neden hep } \\
\text { bu kadar canlısın?" demek. }\end{array}$ & $\begin{array}{r}\text { Kültürel altyapını } \\
\text { geride bırak. }\end{array}$ \\
\hline $\begin{array}{l}\text { İkinci sinıf } \\
\text { vatandaş } \\
\text { muamelesi }\end{array}$ & $\begin{array}{l}\text { Beyaz müşteriye hizmette } \\
\text { öncelik vermek. }\end{array}$ & $\begin{array}{r}\text { Beyazlar daha değerli } \\
\text { müşterilerimizdir. } \\
\text { Sizler ise } \\
\text { değersizsiniz. }\end{array}$ \\
\hline $\begin{array}{l}\text { Ortamsal } \\
\text { kasitsız } \\
\text { hakaretler }\end{array}$ & $\begin{array}{l}\text { Televizyonda ağırlıklı } \\
\text { olarak beyazların } \\
\text { görünmesi, okul vb. yerlere } \\
\text { beyaz devlet büyüklerinin } \\
\text { isimlerinin verilmesi. }\end{array}$ & $\begin{array}{r}\text { Siz buraya ait } \\
\text { değilsiniz. Buradan } \\
\text { daha öte başarılı } \\
\text { olamazsınız. }\end{array}$ \\
\hline
\end{tabular}

\section{Yöntem}


$\mathrm{Bu}$ araştırmada ülkemizde bulunan göçmenlerin ve yabancı öğrencilerin maruz kaldıkları kasıtsız hakaretleri ortaya çıkarmak amaçlanmıştır. Bunun için katılımcılara sadece "Türkiye'de sizin kültürünüze ve etnik farklılı̆gınıza yönelik kasıtlı ya da kasıtsız kırıcı, incitici söz ve davranışlara maruz kallyor musunuz?" sorusu yöneltilmiştir. Soru katılımcılara bireysel ve grup halinde sorulmuş, bireysel görüşmeler ses cihazıyla kaydedilirken grup görüşmelerinde üzerinde sorunun yazıldığı kâğıt katılımcılara dağıtılmıştır. Yazması yetersiz olan gruplarda ise cevaplar sözlü olarak alınmış ve not tutmak suretiyle derlenmiştir.

Görüşmeler İstanbul, Sakarya, Kocaeli, Urfa, Ankara'da gerçekleştirilmiştir. Aralarında üniversite, lise, ortaokul ve ilkokul öğrencilerinin bulunduğu gruplar, öğrenci velileri, doktorlar ve öğretmenler gibi çeşitli meslek grubu mensupları ve ev hanımları ile görüşülerek karşılaştıkları kasıtsız hakaretleri anlatmaları istenmiştir. İlk ve ortaokul öğrencileriyle gruplar halinde görüşülürken diğer katılımcılarla bireysel görüşülmüştür. İlkokul, ortaokul ve üniversite öğrencilerinin tamamı Sakarya'da, geri kalan katılımcılar ise diğer şehirlerde ikamet etmektedir. Araştırmaya katılan ilk ve ortaokul öğrencilerinin tamamı Suriyeli ya da Iraklı, diğer katılımcılar ise değişik milletlere mensuptur.

Görüşmeler sonucunda elde edilen veriler kısaca rapor edilmiş ve belli başlıklar altında özetlenmeye ve yorumlanmaya çalıșılmıştır.

\section{Bulgular ve Yorum}

\subsection{Yakıştıramama}

En sık görülen kasıtsız hakaret bu tür yapılanlardır. Sadece sıradan vatandaşlara karşı değil doktor ve öğretmen gibi meslek sahibi olanlara da bu türden hakaretler yapılmaktadır. Doktor ve öğretmen olduğunu söyledikten sonra şaşırılması ve ısrarla sorulması çok rahatsız edici bulunmuştur. 
Dr.1: Ben Türkiye'ye geldiğim ilk zamanlarda iş başvurusu yapmıştım ve olumsuz karşılandı. Oradaki görevli bana "Sen gerçekten doktor musun? Suriye'de tıp fakültesi var mı ki? " diye sorup yüzüme karşı gülümsedi. Kendimi o kadar kötü hissettim ki keşke savaşta ölseydim diye düşündüm.

Öğretmenlik yapan bir katılımcı kendisine iyi niyetle de olsa sorulan bu tür sorulardan rahatsız olduğunu ifade etmektedir.

Öğretmen 5 (Suriyeli/İstanbul): Okulda samimi oldukları bir Türk öğretmen arkadaşı ile kendisinin araba kullanmasından dolayı "Sen Suriye'de iken araba kullanıyor muydun? Yoksa ehliyeti buradan mı aldın?" ifadesine Suriye uyruklu öğretmen arkadaşımız "Biz sizlerle aynı imkanlara sahibiz. Sadece bizde son 5-6 yıldır bir savaş ortamı mevcut."

Öğrenciler arasında akranlarına göre iyi düzeyde İngilizce bilen öğrenciler de benzer durumla karşılaşmaktadırlar.

"Siz Suriye'de İngilizce eğitimi almış mıydınız?" "Suriye'de yabancı dil öğretimine bu kadar önem veriliyor mu?" gibi sorulara öğrenciler "Bizler aynı sizler gibi bir yaşama sahiptik hocam. Biz de savaş olmadan önce aynı sizin gibi yaşıyorduk."

Öğretmen olduğunu söyleyen bir katılımcının anlattıkları bu konu için çarpıcı bir örnek teşkil etmektedir.

Öğretmen 2 (Harran): Ben Türkiye'ye geldikten sonra beni Harran Kampına gönderdiler. Kampa yerleşmek için 3 gün dişarıda bekledik. Sıra bana geldiğinde memur bana birkaç soru sordu. Sorulardan biri şuydu: "Suriye'deyken mesleğiniz neydi?" Ben de "Öğretmenlik yapıyordum” dedim. Görevli gülerek "Hiç öğretmene benzemiyorsun.” dedi. Ama oradaki görevli empati kursaydı benim haftalarca dışarıda kaldığımı, günlerce yemek yemediğimi, günlerce banyo 
yapmadığımı ve en önemlisi savaştan kaçmış bir mağdur olduğumu anlayacaktı. İşte o an içimden şu geçti. Keşke savaşta ölseydim de bu lafları duymasaydım dedim. Umarım sizler Türkler bizim yaşadığımız durumu yaşamazsınız. Son olarak Türkiye devletine sonsuz şükranlarımı sunuyorum. Bizler her zaman Türkiye'ye dua edeceğiz.

Katılımcıların kendilerini rahatsız eden davranışlardan biri de söylediklerine inanılmaması ve kendilerine güvenilmemesidir.

Öğretmen 1 (Harran): Ben Türkiye'ye yerleştikten sonra Harran Kampinda camide bir anons duydum. "Okul hazır. Suriye'nin çocukları cahil kalmasın öğretmen olan gidip ilçe Milli Eğitim Müdürlügü̈'ne gidip müracaat etsin." Ben de hemen gidip müracaat etmek istedim. Oradaki memur "Siz ne öğretmenisiniz?" diye sordu. Ben de "Rehber öğretmenim" dedim. Bana bakıp "Yalan söyleme. Suriye'de Rehber öğretmeni var mı?” dedi. Sonra devam etti. "Benim bildiğim Suriye'de sadece sınıf öğretmenliği var." dedi. Ben de o anda dışarı çıkıp ağladım. Öğretmenliğe de kayıt yapmadım.

Gusun: Öğretmenim, benim Suriyeli olduğuma başta inanmıyorlar. Beyaz tenli olduğum için sen nasıl Arapsın diyorlar.

Benzer durum Shenoy-Packer (2015)'ın çalışmasında bazı katılımcıların "Esmer değilsin, nasıl Meksikalısın?" sorularına muhatap oldukları şeklinde rapor edilmiştir.

\subsection{Küçük Görülme}

Katılımcıların en çok şikayetçi oldukları konulardan biri de kendilerinin sadece yabancı oldukları için beğenilmemesi ve küçük görülmeleridir.

Dr.2: Ben cerrahım. Ben hastanede çalışıyorum ama 
bana "Sen ameliyat yapamazsın çünkü Türk doktor değilsin" diyorlar. Bunu her duyduğumda Suriyeli olmak suç mu diyorum ve çok üzülüyorum.

Dr. 4: Bir gün bir hastalık ve tedavisi üzerinde doktor arkadaşımla İngilizce sohbet ediyorduk. O, Türk ben Suriyeliyim. Ben o konuda yeterince bilgiye sahip olduğum halde bana "Sen ne anlarsın" dedi. 0 an sustum sadece üzgün bir şekilde yüzüne baktım. Ertesi gün araştırmış ve benim söylediklerimde haklı olduğumu görmüş. Gelip özür diledi ama o anda hissettiğim ötekileştirilmişlik ve küçümsenmiş hissini uzun süre atamadım içimden.

Öğrenciler Türk arkadaşlarının verdiği cevaplara öğretmenlerinin bir şey söylememesi, aynı cevabı kendileri verdiğinde kendilerini kıracak ve üzecek cevapların verildiğini beyan etmektedirler.

Öğrenci 2: Ben Türkiye’ye yerleștikten bir süre sonra okula gitmeye başladım. Türkçe öğretmenimiz bize ödev vermişti. Ben o gün ödevimi yapamadım. Çünkü Suriye'den dayılarım geldi. Sabah okula gittim. Öğretmenimiz ödevleri kontrol etmeye başladı. Sıra bana gelince öğretmenim "Ben ödevimi yapamadım çünkü bize misafir geldi” dedim. Öğretmenin bana bakıp inanmayarak "Hadi ya size de misafir geliyor mu? Konteynır de yer var mı?" diye söyledi. Ben orada keşke yer yarılsa da içine girsem dedim. $O$ anda öğretmene biz de insanız bizim de akrabalarımız var. Biz de insanız demek istedim. Ama diyemedim.

Toplumda göçmenlerin aynı işi yapmalarına rağmen daha düşük ücretle çalışmaları gerektiğine dair bir kanaat oluştuğu görülmektedir.

Dr. 3: Bana biri aldığım maaşı sormuştu ve ben de söylemiştim. Bana "Bir Suriyeliye göre iyi maaş alıyorsun" demişti. Ben doktorum ve çok olmayan aldığım parayı sırf Suriyeliyim diye çok görmüştü. Bunu her hatırladığımda 
kendimi çok dışlanmış ve hakarete uğramış hissetmişstim.

Bazen şaka yoluyla da olsa kırıcı olabilecek cümleler söylenilebilmektedir.

Üniversite öğrencisi: Yemekhane sırasındaki üniversiteli Afrikalı öğrenci için "Afrikalı ya ondan zayıf" diye aralarında konuşması.

Yere düştügü için alay edilmek de üzücü olmaktadır. Fakat bu durum göçmen olmasından daha çok yere düşmek ile de ilgili olabilir.

Haya: Hocam, serviste şoför ani fren yapınca yere düştüm ve bunun sonucunda bazı arkadaşlarım benimle alay ettiler.

\section{3. İsimleriyle Hitap Edilmemesi}

Katılımcıların rahatsız oldukları ve kendilerini dışlanmış hissettikleri konulardan biri kendilerine isimleriyle değil geldikleri memleket ile hitap edilmesi ve lakap olarak takılmasıdır.

Dr. 5: Ben bir doktor olarak hangi milletten olursa olsun hatta dilini bile bilmediğim insanları muayene etmek ve sağlıklarına kavuşturmak isterim. Fakat burada bu mümkün olmadı ve sadece Suriyeli hastalara bakmama izin veriliyor. Sürekli bana "Suriyeli doktor" denilmesi beni üzüyor. Tamam ben Suriyeliyim ama neden Türk doktorlara Türkiyeli doktor demiyorlar. Sadece sürekli kendimi yabancı hissediyorum bunu duyunca. Yoksa başka bir sakıncası yok.

Sadece doktorlara değil öğrenciler arasında da bu tür lakaplar takılmaktadır. Çalıştığı okulda Suriyeli öğrenciler de bulunan bir öğretmenin yaptı̆̆ı görüşmelerde öğrencilerin kendilerine isimleri yerine "Suriyeli" diye hitap etmelerinden duydukları rahatsızlığı dile getirmişlerdir. 
19 yaşındaki Suriyeli üniversite öğrencisi: Eskiden çalıştığım iş yerinde insanlar bana "Arap" diye sesleniyorlardı. Çok üzülüyordum.

Aynı şekilde bu durumdan Afrikalı öğrencilerin de şikayetçi oldukları görülmektedir.

Yükseköğrenim için ülkemize gelen yabancı uyruklu öğrencilerde ülkemize geldiklerinde farklı söylemlerle karşı karşıya gelebilmektedir. Örneğin Afrika asıllı bir öğrenciyle yaptığımız bir konuşma esnasında Afrikalı öğrenciler için "renkli çocuklar" diye bir söylemde bulunduğumuzda öğrenci bize böyle bir ifade kullanmamamızın daha uygun olacağını ifade etti.

Okul: Türk çocukların siyahi bir çocuk gördüklerinde "Aaa bakın çikolata" dediklerine şahit oldum.

\subsection{Olumsuzlukların Sebebi Görülmeleri}

Özellikle resmî kurumlarda çalışanlar katılımcıların şikayetçi oldukları konuların başında gelmektedir.

Öğretmen 1: Ben Arapça öğretmeniyim. Türkiye'de öğretmen olarak çalışmaya başladığım ilk günlerde bir Türk öğretmen "Türkiye'de atanamayan o kadar çok öğretmen varken devlet sizi işe aldı. Kıymetini bilecek misiniz göreceğiz?" demişti. 0 an boğazım düğümlenmiş, kendimi dışlanmış ve küçümsenmiş hissetmiştim. Günlerce atamadım bunun moral bozukluğunu.

Ülkemizde yaşanan ekonomik sıkıntıların yanı sıra güvenlik sorunlarının nedeni olarak da göçmenlerin görülmesi sık karşılaşılan durumların başında gelir.

Öğretmen 2: Bizim okulda müdürümüz bana "Size çok para harcadığı için devlet bizim faturaları yükseltiyor. Size 
sürekli para harclyoruz" demişti. 0 an kendimi Türkler için bir yükmüş gibi hissettim. Hem çok utandım hem mahçup oldum. Maaşımı çekmeye giderken bile bakıyorum eğer kimse yoksa gidip çekiyorum. Yoksa bekliyorum.

Benzer sıkıntılar YTB bursu ile ülkemizde öğrenim gören yabancı öğrenciler tarafından da aktarılmıştır.

Suriyeli ve Afganistanlı üç üniversite öğrencisi "Siz bizim ülkemizde bedava okuyorsunuz, biz ise para veriyoruz. Para size harcanıyor." şeklinde mikro-saldırı içeren tepkiler aldıklarından artık Türkiye'de YTB bursu ile okuduklarını söylemeye çekinmektedir.

$\mathrm{Bu}$ öğrencilere devletimiz tarafından verilen maddi destek öfke konusuna dönüşmeye başlamıştır. Ülkemizin dönemsel olarak yaşadığı maddi zorlukların insanlarımızın böyle düşünmesine katkısı olabilir.

\subsection{Dillerinin Anlaşılmamasından Kaynaklanan Suçlama}

Katılımcıların kendi aralarında veya tercüman vasıtasıyla yaptıkları konuşmaların muhatapları tarafından yanlış anlaşılması ve farklı anlamlar yüklenmesi karşılaşılan bir diğer sorunlu durumdur. Bir katılımcı iyi niyetle yaptığı açıklamaların tercümanı tarafından özetlenmesi üzerine kendisinin ayrıntılı konuştuğu için uyarılmasından çok rahatsız olduğunu ifade etmektedir.

Öğretmen 6 (İstanbul): Görev yaptığı kurumda müdür ile iletişimi sırasında Türkçe konuşmayı bilmediği için Türkçe ve Arapça dillerini bilen bir arkadaşı aracılığı ile anlaşmaya çalışmıştır. Bu iletişim sırasında Arapça cümleler kullanan arkadaşım tercümanın üç dört kelime ile ifadesinden sonra, kurum müdürünün şu sözleri ile karşılaşmıştır. "Sen bu kadar uzun sadece bunları mı anlattın?" Bu da yetmezmiş gibi kurum müdürü tercüman aracılı̆̆ 
anlatmana gerek yok. Bir kelime söyleyecekken neredeyse o kelimenin tarihçesinden bahsediyorsunuz. Bizlerle tekrar iletişime geçerken isteğinizi kısa ve öz bir şekilde anlatın" sözlerini sarf etmiş, arkadaşımız bu durumdan dolayı bir üzgünlük yaşamıștır. "Halbuki ben kelimeleri uzatmadım derdimi uygun bir dille anlatmaya çalışmıştım" sözleri ile bize serzenişte bulunmuştur.

Kendilerine güvenilmemesine bir diğer örnek aralarında yaptıkları konuşmalarının kendi aleyhlerinde yapılıyor olmalarına dair olan kanaattir.

Öğrencilere şaka mahiyetiyle söylenen "Siz acaba sürekli bize küfür mü ediyorsunuz?" cümlesi öğretmenin anlamamış olmasından dolayı öğrencilerin kendi arkadaş grubu ile aralarında konuştukları her Arapça ifadenin böyle algılanmasının nedenini kendilerini sürekli kötü işler yapan insanlar olarak düşündüklerini ifade ediyorlar.

\subsection{Ayrımcılık ve Dışlama}

Özellikle okul, çarşı ve toplu ulaşım araçları gibi yerlerde görülen ayrımcı ve dışlayıcı tavırlar kasıtsız hakareti aşıp doğrudan ayrımcılık, doğrudan taciz ve düşmanlığa girmektedir.

Oto tamircisi (Türkmen) İstanbul: Mısır'dan gelen Arap arkadaşlarını ağırlamak için bir restorana gitmişler. Kendi aralarında Arapça konuştuklarından dolayı restorana yeni giren bir kişi “Aaa burada da mı Suriyeliler var?" diyerek arkadaşlarına dönmüş ve arkadaşlarına da bir başka yerde yemek yemeyi teklif etmiştir. Bu olayı yaşayan öğrenci velisi kendisinin bir Türkmen olduğunu ve hiçbir zaman ne Araplara karşı ne de yerleşik oldukları semtte bulunan diğer milletlerden olan insanlara bu şekilde davranmadığını ifade ederken "Biz Türkler özümüzü unutmuşuz ağabey. Bizler Suriye'de yerleşik halkın Irak'tan göçüp gelen insanlara karşı kötü davranmalarından dolayı bu haldeyiz. Eğer ki bizler de 
böyle davranırsak sonumuz onlardan daha kötü olacaktır." sözlerini söylemiştir.

7. sınıf öğrencisi Ayah: Hocam, kantinde boş sandalye olmasına rağmen bazı öğrenciler boş sandalyeyi dahi bana vermek istemiyor dolu diyorlar, yanıma bile oturmaktan kaçınıyorlar.

Mays: Öğretmenim annemle pazarda meyve seçerken pazarcının sert tavrıyla karşılaştık orda poşet alıp kendimiz meyve seçmek istedik pazarcı buna izin vermedi ve poșeti sert şekilde elimizden alarak "Siz bari yapmayın poșete koyduğumu alacaksınız" dedi. Biz de almadan ayrıldık.

7. sınıf öğrencisi Betül: Öğretmenim kardeşimle hafta sonu mahallemizdeki parka gittik. Kardeşimi salıncakta sallıyordum. Biraz sonra mahalleden arkadaşlarım geldi. Kardeşimi salıncaktan zorla kaldırdılar. Halbuki ben kardeşime bir hafta önceden parkta güzel vakit geçireceğiz diye söz vermiştim. Onlar öyle davranınca eve gitmek zorunda kaldık, kardeşim çok üzüldü.

Gusun: Hocam okuldan sonra annemle pazara gittik. Pazara giderken yolda okuldan arkadaşımla karşılaştım selam vermek istedim. Arkadaşım gülerek anlamını bilmediğim bir şey söyledi ben o an bunu anlamadım gülümseyerek yanından ayrıldım sonra Türkçeyi öğrendikten sonra arkadaşımın bana söylediği şeyin aşağılayıcı küçük düşürücü bir söz olduğunu öğrendim, kendimi çok kötü hissettim. Sadece selam vermek istemiştim. Öğretmenim siz yolda gördüğünüz arkadaşınıza selam vermez misiniz? Bunlar bizim selamımızı bile almıyorlar.

Marya: Öğretmenim mahalledeki arkadaşlarım doğum günümü bildikleri halde doğum günümü kutlamadılar halbuki ben onların doğum gününe katılmıştım.

Maria: Hocam, hafta sonu gondolda bütün herkes 
eğlenip bağırıyordu. Ben de bağırdım. 0 kadar kişinin içinde bana kızdılar, "Madem korkuyorsun binmeyeceksin, kendi ülkenizde eğlensenize! Burada ne arıyorsunuz?” dediler.

Mecid: Bakkal alışverişini tamamladık, eve dönerken yolda kardeşim çikolata isteyince markete tekrar gittim ancak bakkal bana kızıp bağırdı niye tek tek söylüyormuşum aynı anda almamışım. "Sizler hep böylesiniz zaten" gibi aşağılayıcı birkaç söz söyledi. Bu olaydan sonra bir daha o bakkaldan alışveriş yapmıyorum. Öğretmenim siz alacağınız bir şeyi unutup tekrar gittiğinizde niye yine geldin, siz hep böylesiniz diye tepki veriyorlar $\mathrm{m}$ ?

Mays: Öğretmenim, Avm'de dolaşırken insanların yüzümüze karşı "Bunların burada ne işi var? diye bize söylediler.

Nebi: Öğretmenim, okul servisinde oturduğum yerde bazı öğrenciler bana karışıyor ve burası bizim ülkemiz sen bir şey diyemezsin diyorlar.

Kadın. 24 yaşında. Ürdün vatandaşı üniversite öğrencisi: Oda arkadaşıma göre Suriyeliler Kent Park'ta çekirdek yemekten başka bir şey yapmıyorlar.

Erkek. 25 yaşında. Afganistanlı üniversite öğrencisi: Yüzümüze karşı "Ben Afganları sevmem” diyen bile oluyor.

Yemen ve Afganistanlı üç üniversite öğrencisi Türkiye'de hoş karşılanmadıklarını hissettiren "Niye buraya geliyorsunuz?", "Kendi ülkenizde okuyun", "Siz burada savaş öğretiyorsunuz.", "Neden başka bir yer değil de Türkiye'yi seçtin?" ve "Siz burada ne yapıyorsunuz?" ifadeleriyle karşılaşmıştır.

Orta Doğulu öğrencilerin bazıları Suriyeli olmasalar dahi Suriyeli zannedilip "Neden ülkendeki savaştan kaçtın?" şeklinde tenkitler aldıklarını dile getirmiştir. 
Özellikle yetişkinlerin ilk geldiklerinde çektikleri sıkıntıların başında kendilerinden yüksek fiyat istenmesi gelmektedir.

Öğretmen. 4: Ben kiralık ev aramak için mahalle mahalle dolaştım. Şimdi oturduğum evi çok zor buldum. Kiralık ilanı yazan birkaç eve gitmiştim. Bana "Suriyelilere ev kiralamıyoruz çünkü onlara güvenmiyoruz" dediler. Biliyorum aramızda kötü insanlar da var ama hepimiz kötü değiliz. Niye bize böyle davranıyorsunuz?

Ev kiralamalarında karşılaştıkları fahiş fiyatlardan şikayetçiler. Türklerden istenenden daha fazla kira bedeli istendiğini dile getiriyorlar ve bunun nedenini sorduklarında Arap oldukları, evde çok kişi kaldıkları, evleri temiz bırakmadıkları gibi cevaplar almışlar. İşyerlerinin kendilerini daha ucuza çalıştırmak istemelerinden de şikayetçiler.

Hem bu çalışmanın hem de Er (2018)'in çalışmasının ortaya koyduğu bir gerçek de yabancı uyrukluların resmi kurumlarda zaman zaman anlayışsız tutumlarla karşılaştığı hatta resmi işleyişi bilmedikleri için azarlandıklarıdır.

Iraklı üniversite öğrencisi: Yabancı uyruklularla anlaşmak çok zor diyorlar bize.

Bir başka ülkeden geldiklerini söyledikleri halde kendilerine ayrıca yabancı denilmesi katılımcıları rahatsız etmektedir.

Öğretmen: Sınıfta öğrenci ve öğretmenleri tarafından sorulan "Nerelisin" sorusuna öğrencilerin verdikleri cevaplar karşısında "Yabancısın yani" cevabını almaları öğrencileri üzmektedir.

8. sınıf öğrencisi Merva: Öğretmenim başka bir 
sınıftaki arkadaşımdan kalem almak için sınıfa girmek istediğimde beni sınıfa almak istemiyorlar. "Yabancısın sınıfımızdan çık! İstemiyoruz seni” diye kapıyı yüzüme kapatiyorlar.

Ayrımcılık ve dişlama başlığı altında değerlendirilebilecek bir diğer durum da "ikinci sınıf vatandaş muamelesi" (Sue vd., 2007) yapılmasıdır. $\mathrm{Bu}$ bir tür mikro-hakarettir ve örneklerine araştırmamızda sıkça rastlanmıştır. Araştırmaya katılanlar "Yabancıyız diye bizden kaçıyorlar.", "Suriyeli deyince çekiniyorlar." şeklinde durumu dile getirmişlerdir.

Azeri bir üniversite öğrencisi "Bu ülkede kalmak için izin aldın mı?” sorusuna muhatap olmuştur.

Filistinli bir üniversite öğrencisi ise "Farklı milletlerden insanların bir arada olduğu ortamlarda batılılara daha fazla ilgi gösterilmesine artık alıştım" şeklinde sitem etmiştir.

Filistinli başka bir üniversite öğrencisi marketlerden alışveriş yaparken görevli personelin kendilerini göz hapsinde tuttuğundan şikâyet etmiştir. Bazı etnik grupları diğerlerine göre "suça daha meyilli görme" (Sue vd., 2007) yine mikro-hakaretlere dahildir.

Maalesef burada sıralanan durumların hepsi ülkemizdeki yabancı uyruklu şahıslara kendilerini ikinci sınıf bireyler olarak hissettirmekte ve onları dışlamaktadır.

\subsection{Türklere veya Bir Başka Millete Benzediklerinin Söylenmesi}

İnsanların muhataplarını övmek için söyledikleri sözlerin de kırıcı olabildiğine dair güzel örneklerden biri Türklere benzediğini söylemektedir. Dolaylı yoldan mensubu bulunduğu milletin beğenilmediğini çağrıştıran bu ifade katılımcıları çok rahatsız etmiştir. 
Öğrenci 1: Ben Türkiye’ye ilk geldiğim zamanlarda Harran kampına yerleşmek için kayıt yapmamız lazımdı. Benim sıram geldiğinde oradaki görevli bana bakıp ismimi sordu. İsmimi sorduktan sonra bana bakıp "Sen Türklere benziyorsun" dedi. Ben orada Suriye'ye dönmek istedim. 0 zaman şunu düşündüm Arapların Türklerden farkı nedir diye düşündüm.

Bunun bir benzerini Almanya'da yaşayan bir Türk ifade etmiştir.

50 yaşında Almanya'da yaşayan Türk Ahsen: "Hiç Türk'e benzemiyorsun, modern görünüyorsun." cümlesine maruz kalmıştır. Aslında kişiyi övüyor gibi gözüken bu söylemden Türklerin modern olmadı̆̆ı anlamı çıkıyor.

Özellikle ülkemizde siyah tenlinin Arap, her çekik gözlünün de Japon'a benzetildiği düşünüldüğünde bu tür benzetmelerin sık yapıldığı düşünülebilir. Özellikle Kırgızistan ve Kazakistan'dan gelenlerin Japon ve Çinli benzetilmesine maruz kaldıkları görülmektedir.

Öğretmen (Kazakistan): Bu tür ifadelerle çok sık karşılaştığını ifade etti. Yolda yürürken bile bazı insanların "Japon'a bak" türünden cümlelerini sık sık duyduğunu söylemiştir.

İranlı olduğu halde kendisine Arap denilmesinden rahatsız olan bir katılımcı kim olduğunu söylediği halde ısrarla devam edilmesinden şikayet etmektedir.

Amir Mohammad:(46 yaşında erkek) Amir'in en çok şikayetçi olduğu şey, çalıștığı yerde bazı kişilerin kendisine "Arap" diye hitap etmesi. Kendisine adıyla hitap edilmesini istediği halde bu kişilerin israrla "Arap" diye seslenmesi Amir'i üzüyor. Hiçbir irkla sorunu olmayan Amir Fars kökenli, kendisinin Arap sanılmasını da anlıyor fakat bu kişilere durumunu anlattığı halde neden ısrarla kendisine 
Arap denildiğine pek anlam veremiyor.

\subsection{Türkçelerinin Yetersiz Olduğunu Söylemek}

Katılımcıların kendileri ile ilgili söylenen ve rahatsız oldukları konulardan biri de Türkçelerinin yetersizliğidir. İyi niyetle ve korumak amacıyla da söylenmiş olsa rahatsız etmektedir.

Öğretmen (Harran): Türkçeye hâkim olan Suriye kökenli öğrencim derse katılırken duraksadığında arkadaşlarının sık sık "-o Türkçe bilmiyor" șeklinde iyi niyetli yardımcı olmaya yönelik ifadelerini örnek verebilirim.

Çocuklar oyunlarda "Sen Arap'sın" ya da "Sen Türkçe bilmiyorsun, bizimle oynama" diye söylemlere maruz kalmaktadır.

Sadece Suriyelilere değil, 12 yaşında annesi Rus babası Türk bir öğrenci de aynı durumla karşı karşıya kalabilmektedir:

Türkiye'ye yeni taşındığı için Türk kültürüne ve diline hakim olmayan Faruk, arkadaşlarının kantine giderken söyledikleri "Sen gelme, biz sana da alırız" cümlelerine maruz kalmakta.

Yardımsever gibi gözüken bu yaklaşım, bir yandan öğrencinin yabancı olduğuna, Türkçesinin yetersiz olduğuna vurgu yapmakta ve öğrenciyi üzmektedir.

Mecid: Öğretmenim mahallemizde top oynamak istiyorum çocuklarla. Çoğunlukla beni oyunlarına almak istemiyorlar. Nedenini sorduğumda sen bizi anlamıorsun, açıklamamı yapalım oyun mu oynayalım diyerek cevap veriyorlar.

Emir: Öğretmenim, okula arkadaşlarımla oynamak için 
top getiriyorum. Ancak getirdiğim topa rağmen beni oyunlarına dahil etmek istemiyorlar. Sen anlamazsın diyerek beni oyunlarına almıyorlar.

Amar: Öğretmenim arkadaşlarım yapabileceklerimi gerçekleştirmeme izin vermiyorlar. Mesela ben yazı yazmak istiyorum dur sana yardım edelim, sen yazamazsın diyerek önümden defterimi alarak yazmaya çalışıyorlar.

Maria: Hocam Türkiye'ye ilk geldiğimizde Hatay'da kaldık. Orada gittiğimiz ilkokulda dil bilmediğim için kendimi ifade edemiyordum ve arkadaşlarım da sınıfta ben yokmuşum gibi davranıyorlardı.

\subsection{Merak Saikıyla Sorulan Sorular}

İnsanların iyi niyetle ve tamamen merak amacıyla sordukları birtakım sorular da rahatsız edici olabilmektedir.

İsveçli bir arkadaşım ise farklı milletten insanların bazen ona takılmak için bazen de safça "Ülkenizde yolda giderken kutup ayısıyla karşılaşıyor musunuz?" ya da "İglo eviniz var mı?” türünden sorular sorduklarını anlatmıştır.

Göçmenleri rahatsız eden sorulardan biri de kendilerine ne zaman döneceklerinin sorulması.

Öğretmen 3: Ben İngilizce öğretmeniyim. Türk arkadaşlarım da var. Bana çok iyi İngilizce konuştuğumu söylüyorlar. Mutlu oluyorum onlardan bunu duyunca. Fakat bana bazen "Suriye'ye ne zaman döneceksiniz?" diye soruyorlar. Tamam belki kötü bir niyet yok ama onlar da biliyor orada savaş var. Ben o anda bir evde çok kalmış misafir gibi hissediyorum, kendimi. Keşke savaş bitse ve daha fazla size yük olmasak. 
Shenoy-Packer (2015)'ın Amerika'da çalışan göçmenler ile ilgili araştırmasında da göçmenlerin değişik aksanlarını fark edenlerin sıklıkla "Nereden geldin? Ne kadar zamandır buradasın?" sorularını yönelttiği ile ilgili bulguları bizim bulgularımızı desteklemektedir.

$\mathrm{Bu}$ soruların hepsi iyi niyetle soruluyor olsa bile aynı kişiye birden fazla kişinin farklı zamanlarda sorması rahatsı edici olabilmektedir.

\subsection{Cinsiyet Ayrımı}

Keihan Etemadi (İranlı 42 yaşında kadın): Keihan çalışan bir kadın ve işi gereği akşam geç saatlerde eve dönmekte. Eve dönüşlerde dolmuşu kullanan Keihan dolmuşlarda karşılaştıkları erkeklerden ne iş yaptığına ve neden bu saatte dışarıda olduğuna dair sorularla karşılaşmaktan şikayetçi. Kendi ülkesinde bu tür sorularla karşılaşmadığını ve bu durumdan çok rahatsız olduğunu dile getiren Keihan birçok kişiden geç saatte dışarıda olmanın güvenli olmadığına dair telkin almaktan sıkılmış durumda ve özel hayatının yakınları hariç kimseyi ilgilendirmemesi gerektiğini düşünüyor.

Mehrzad Seif (İranlı 24 yaşında kadın): Mehrzad başı açık bir bayan, yaşamış olduğu mahalledeki arkadaşlarının kendisine yönelttiği “İran'da başı açık geziliyor mu?” ya da "Orada kapalısın madem, neden burada başını açtın?" sorularından sıkılmış durumda. Türkiye'de yaşayan kadınların yıllardır giyimlerinde özgür oldukları halde neden hala böyle bir soruyla karşılaştığına pek bir anlam veremiyor Mehrzad.

8. sınıf öğrencisi Zeynep: Öğretmenim peçe taktığım için arkadaşlarım kıyafetime gülüyorlar, benimle alay ediyorlar. 


\subsection{Yaygınlaşmış Kanaatlere Yahut Önyargılara Bağlı Sorular/Yorumlar}

Ülkemizde birtakım ülke ve milletler için yerleşmiş kanaatler ve önyargılar bulunmaktadır. Bu yargı tarihin bir döneminde yaşanmış ve kalmış olsa bile halen devam etmekte ve zaman zaman kırıcı olabilmektedir.

Ürdünlü Sevsen 25 yaşında: "Sen elinle mi yemek yiyorsun?" diye soranlara içerlemiş, tüm Arapların aynı olmadığını kendisinin elle yemek yemediğini ifade etmiştir. "Siz nasıl yemekler yiyorsunuz?" sorusuna maruz kalmış. Sohbet "Sizin yemekleriniz çok baharatlı, kötü kokuyor, sana da kokmuyor mu?" şeklinde ilerlemiştir.

Ortadoğu'dan gelen öğrencilerin sıkça karşılaştığı diğer önyargılar da "Araplar çok eşlidirler, çölde yaşayan bedevilerdir" şeklindedir.

Halil Bilal (Kocaeli) Suriye Türkmen: Kendisi buraya ilk geldiğinde bir yemek esnasında "zeytine" el uzatmış ve zeytini eliyle yemiş. Yanındaki Türkiye Türkü bir vatandaş tarafından da uyarıldığını anlattı. Burada müdahale eden vatandaş zeytinin el ile değil de çatalla yenmesi gerektiğini söylemiş ve şöyle bir söylemde bulunmuş: “Aynı Araplar gibi elinle yemek yiyorsun."

Azerbaycanlı bir üniversite öğrencisi “Azerbaycanlıları Azeri sanıyorlar. Halbuki Azeriler İran'da yaşayan Fars kökenli bir topluluktur. Biz ise Azerbaycan Türküyüz, Azerbaycanlıyız ama bunu burada anlatamıyoruz." şeklinde yanlış bilgiden doğan ciddi bir önyargıya maruz kaldıklarını dile getirmiştir.

Rusya'da yaşayan Kafkas üniversite öğrencisi: Ruslarla ilgili ön yargılar hep bize mal ediliyor. 
Filistinli bir üniversite öğrencisinin TÖMER'de yaşadığı olay eğitimcilerin bile önyargısız olamadıklarını ve durumun vahametini göstermektedir: "Dönem başında öğretmen hepimizle tanışırken, bize sıra gelince Filistinlileri zaten tanıdığını, bu yüzden ülkemizi ve kültürümüzü anlatmamıza gerek olmadığını söyledi. Bu bize ırkçılık gibi geldi ama öğretmen bunu fark etmedi."

Önyargllara maruz kalan bireyler muhataplarını ikna etmekte zorlanmaktadırlar:

24 yaşındaki Ürdünlü üniversite öğrencisi: Ben herkes öyle değil, göstermeye çalışıyorum.

19 yaşındaki Suriyeli üniversite öğrencisi: Umarım ki Türk halkı anlasın ki tüm Araplar öyle değil. Arabistan'da bilim adamları gibi çok değerli insanlar var. Sizin de muhakkak iyi ve kötüleriniz yok mu?

Bilgisizlikten doğmuş ve yine milliyet ile ilgili bir büyük ön yargı da "Türkiye'deki her Orta Doğulu Suriyeli'dir" şeklinde kendini göstermiştir. Irak, Afganistan ve Filistinli öğrenciler bu konuda mağdurdur. Burada tüm yabancılar içerisinde Suriyelilere karşı toplumumuzdaki olumsuz fikirlerin daha yoğun olması etkili olabilir. Er (2018)'in çalışmasına katılan 10 üniversite öğrencisinden sadece Suriyeli bir tanesinin ülkesi ile ilgili ayrımcı bir tutumla karşılaştığını beyan etmesi de bulgumuzu doğrular niteliktedir. Türk soylu öğrencilerin böyle bir yakınması yoktur. Orta Doğululara benzememelerinin buna neden olduğu düşünülebilir.

$\mathrm{Bu}$ öğrencilerin yaşadıkları durumların hepsi Sue ve arkadaşlarının kasıtsız hakaretler ile ilgili belirledikleri üç temel alt başlıktan mikro-hakarete (microinsult) girmektedir. Burada bireyin "kültürel kimliğini aşağılama" (Sue vd., 2007) söz konusudur. 


\subsection{Irkçı Olduğunu Inkâr Etmek}

Göçmenlere karşı mesafeli davranışlardan biri de onlarla diyalog kurabildiğini gösteren cümleler kullanmaktır.

16 yaşındaki Suriyeli Farah: Kendisine için "Benim Suriyeli arkadaşlarım da var." denmesinden incinmektedir.

$\mathrm{Bu}$ durum her ne kadar iyi niyetle söyleniyor olsa da "arkadaşlarım da" ifadesindeki "da" eki muhatabı rahatsız edebilmektedir.

Sue ve arkadaşlarının (2007) çalışmasında tespit edilen "Bir sürü siyahi arkadaşım var.” ifadesi aynı sıkıntının dünyanın farklı yerlerinde de yaşandığının kanıtıdır.

\subsection{Karşılaştırma Yapmak}

Katılımcıların rahatsız oldukları konulardan biri de kendilerinin diğer öğrencilerle karşılaştırılmasıdır.

17 yaşındaki Iraklı Tiba için çoktan seçmeli sınav yapan öğretmeni sınıfa dönerek "Görüyorsunuz ilk Tiba bitirdi, hadi acele edin!” demiştir.

5 yaşındaki İspanyol Nora: Kreşte deve cüce oyunu onarken oyuna adapte olmuştur. Öğretmen, Türk öğrencisi için "Nora bile senden daha iyi yapıyor." demiştir.

$\mathrm{Bu}$ ve benzeri karşılaştırmaların öğrencilerin özgüvenlerine olumsuz etki yapması ve okul başarılarını da düşürmesi kuvvetle muhtemeledir. Bonifacio vd. (2018) çalışmasında görülmüştür ki kasıtsız hakaretlere daha fazla maruz kalan öğrencilerin gelecekle ilgili beklentileri küçülmektedir. 


\subsection{4. Özel Hayata Müdahale}

En sık karşılaşılan durumlardan biri de kllık kıyafetle ilgili rahatsız edici konuşmalardır. Nereden alındığı bilinmeyen bir hak ve yetki ile insanların kıyafetleri hakkında yorumlar yapılmakta, bazen fili müdahaleye kadar gidilmektedir. Yabancıların yöresel kıyafetleri ile ilgili yaşadıkları olumsuzlukların sıklı̆̆ı çok üzücüdür.

Ürdün vatandaşı, aslen Filistinli kadın üniversite öğrencisi: Yöresel örtümüz olan "kufiye" taktığımda oda arkadaşım "Terörist gibi görünüyorsun, beni korkutuyorsun".

Yemenli üniversite öğrencisi ülkesinde erkeklerin giydiği uzun bir klyafet olan "mavaz" giydiğinde "Bu etek gibi şeyi mi giyiyorsun?" şeklinde bir tepki aldığı için artık özel günleri dışında bu kıyafeti giymeye çekinmektedir.

Iraklı bir öğrenci Irak'ta normal karşılanan kıyafetinin burada yadırganmasına son derece üzüldüğünü söyledi. Kendisi arkadaşlarının giyimine yorum yapmayarak onlara saygı duyuyorsa aynı saygıyı onlardan da beklediğini ifade etti.

Ayrıca bir öğrencimiz Iraklı arkadaşının metroda "burka" giydiği için toplum içinde insanlar tarafından azarlandığını aktarmıştır.

$\mathrm{Bu}$ örneklerin Sue ve arkadaşlarının (Sue vd., 2007) kasıtsız hakaretler için belirledikleri en incitici tür olan mikro-saldırılara (microassault) dahil olduğunun altını çizmekte fayda görüyoruz. Ayrıca Lilly vd. (2018) çalışmasında kasıtsız hakaretten muzdarip öğrencilerde depresyon riskinin diğer öğrencilerden 2.14 kat daha fazla olduğunun tespit edildiği de dikkate alındığında bu saldırıların verdiği zarar anlaşılmaktadır.

Yardıma ihtiyacı olmadığı halde yardım etmek. 
Amar Suriye'de şavaş sırasında bir ayağını kaybeden bir öğrenci. Öğrencilerin yapabileceği şeylerde de ona yardım etmeye çalışması örneğin eliyle ilgili sorun yok onun yerine yazmak istemeleri onu kızdırıyormuş.

Nataşa isminin olumsuz çağrışımlarından dolayı o ismi taşıyan herkese aynı şekilde davranılması veya şakalar yapılması da söz konusu olabilmektedir.

25 yaşında İngiliz Nataşa: Türklerin onun ismi için "Adın gerçekten Nataşa mi, neden Nataşa ismi?" gibi sorularına maruz kalmaktadır.

\section{Sonuç}

Yukarıda tablosu verilen bir araştırmada (Sue, vd., 2007) örneklerden yola çıkılarak temalar "kendi ülkende yabancı, zeki görme, renk ayırmazlık, potansiyel suçlu görme, ırkçı olduğunu inkâr etme, hakkaniyetle ilgili söylentiler, kültürel değerleri aşağılama, ikinci sınıf vatandaş muamelesi, ortamsal kasıtsız hakaretler" şeklinde belirlenmişti.

Bizim yaptığımız çalışmada ise karşılaştığımız örneklere bakarak temaları şu şekilde belirledik. 
Tablo 4. Kasıtsız Hakaret Temaları

\begin{tabular}{|c|c|c|}
\hline Temalar & $\begin{array}{l}\text { Kendisine } \\
\text { söylenilen }\end{array}$ & $\begin{array}{l}\text { Göçmenlerin } \\
\text { düșündüğü }\end{array}$ \\
\hline Yakıştıramama & $\begin{array}{l}\text { "Sen gerçekten } \\
\text { doktor musun? }\end{array}$ & $\begin{array}{l}\text { Doktorlar güzel giyinir, } \\
\text { sen güzel giyinmiyorsun } \\
\text { ve görünmüyorsun. }\end{array}$ \\
\hline Küçük görme & $\begin{array}{l}\text { Size misafir } \\
\text { geliyor mu? } \\
\text { Bir Suriyeliye } \\
\text { göre ücretin iyi. }\end{array}$ & $\begin{array}{r}\text { Sizin misafir kabul } \\
\text { edecek kadar yeriniz yok, } \\
\text { eviniz müsait değil. } \\
\text { Aslında Suriyeliler çok } \\
\text { ücreti hak edecek } \\
\text { derecede değiller. }\end{array}$ \\
\hline $\begin{array}{l}\text { İsmiyle hitap } \\
\text { edilmemesi, lakap } \\
\text { takılması }\end{array}$ & $\begin{array}{l}\text { Suriyeli doktor } \\
\text { Renkli çocuklar } \\
\text { Çikolata geldi }\end{array}$ & $\begin{array}{r}\text { Doktor ama Suriyeli, } \\
\text { bizden değil. } \\
\text { Tek ayırıcı özelliği Siyah } \\
\text { olması imiș sanki. }\end{array}$ \\
\hline $\begin{array}{l}\text { Olumsuzlukların } \\
\text { sebebi görme }\end{array}$ & $\begin{array}{l}\text { Atanamayan } \\
\text { birçok öğretmen } \\
\text { varken devlet sizi } \\
\text { atadı. } \\
\text { Devlet size çok } \\
\text { para harcadığ } \\
\text { için faturalar } \\
\text { yükseliyor. }\end{array}$ & $\begin{array}{r}\text { Hakkım ve layık } \\
\text { olmadı̆̆ım bir işi } \\
\text { yapmıyorum. } \\
\text { Bu benim tercihim değil. } \\
\text { Yük olduğumu } \\
\text { düşünmeye başladım. }\end{array}$ \\
\hline $\begin{array}{l}\text { Dillerinin } \\
\text { anlaşılmamasından } \\
\text { kaynaklanan } \\
\text { güvensizlik/ } \\
\text { suçlama }\end{array}$ & $\begin{array}{l}\text { Acaba } \\
\text { anlamıyoruz diye } \\
\text { bizimle ilgili kötü } \\
\text { şeyler mi } \\
\text { söylüyorsunuz? }\end{array}$ & $\begin{array}{r}\text { Bizim her sözümüz } \\
\text { kötülük içermez ya da } \\
\text { sizinle ilgili değil. }\end{array}$ \\
\hline $\begin{array}{l}\text { Ayrımcilık ve } \\
\text { dişlama }\end{array}$ & $\begin{array}{l}\text { Değerinden } \\
\text { yüksek kira } \\
\text { istemek. } \\
\text { Aa burada da } \\
\text { Suriyeliler var. }\end{array}$ & $\begin{array}{r}\text { Nasıl olsa mahkum ve } \\
\text { mecburum, firsat } \\
\text { düşkünlüğü. Zaten zor } \\
\text { durumdayız, bir da siz } \\
\text { zorlaştırmasanız. Neyse } \\
\text { onu verelim. } \\
\text { Onlar ikinci sınıf insan, } \\
\text { biz onlarla birlikte } \\
\text { yiyemeyiz. }\end{array}$ \\
\hline
\end{tabular}




\begin{tabular}{|c|c|c|}
\hline $\begin{array}{l}\text { Başkalarına } \\
\text { benzetme }\end{array}$ & $\begin{array}{l}\text { Türklere } \\
\text { benziyorsun. }\end{array}$ & $\begin{array}{r}\text { Suriyeli olmak kötü bir } \\
\text { șey mi? }\end{array}$ \\
\hline $\begin{array}{l}\text { Türkçelerinin } \\
\text { yetersiz olduğunu } \\
\text { söylemek }\end{array}$ & $\begin{array}{l}\text { O Türkçe } \\
\text { bilmiyor. }\end{array}$ & $\begin{array}{l}\text { O halde ona sormayalım, } \\
\text { onunla oynamayalım. }\end{array}$ \\
\hline $\begin{array}{l}\text { Merak edilip } \\
\text { sorulan sorular }\end{array}$ & $\begin{array}{l}\text { Ne zaman } \\
\text { ülkenize } \\
\text { döneceksiniz? }\end{array}$ & $\begin{array}{r}\text { Ülkemde savaş var, böyle } \\
\text { sorulduğunda kendimi } \\
\text { misafir ve yabancı gibi } \\
\text { hissediyorum ve } \\
\text { üzülüyorum. }\end{array}$ \\
\hline Cinsiyet ayrımı & $\begin{array}{l}\text { Geç vakit } \\
\text { karşılaşılan bir } \\
\text { kadına: Ne iş } \\
\text { yapıyorsun? } \\
\text { İran'da başı açı } \\
\text { geziliyor mu? }\end{array}$ & $\begin{array}{r}\text { Diğer insanların yaptığı } \\
\text { gibi normal bir iş } \\
\text { yapıyorum. Ülkemde geç } \\
\text { vakitler sokaklarda } \\
\text { olurdum ve bu tür } \\
\text { sorularla } \\
\text { karşılașmazdım. }\end{array}$ \\
\hline $\begin{array}{l}\text { Önyargilara bağlı } \\
\text { sorular/yorumlar }\end{array}$ & $\begin{array}{l}\text { Siz elle mi yemek } \\
\text { yiyorsunuz? }\end{array}$ & $\begin{array}{r}\text { Bizde herkes elle yemek } \\
\text { yemiyor. }\end{array}$ \\
\hline $\begin{array}{l}\text { Irkçı olduğunu } \\
\text { inkar }\end{array}$ & $\begin{array}{l}\text { Benim de Suriyeli } \\
\text { arkadaşlarım var. }\end{array}$ & $\begin{array}{r}\text { Aslında ben her şeye } \\
\text { rağmen yabancılarla } \\
\text { arkadaşlık } \\
\text { yapabiliyorum, ben o } \\
\text { kadar da ırkçı değilim. }\end{array}$ \\
\hline Mukayese etmek & $\begin{array}{l}\text { Nora bile senden } \\
\text { iyi yapıyor. }\end{array}$ & Çünkü ben en kötüyüm. \\
\hline $\begin{array}{l}\text { Özel hayata } \\
\text { müdahale }\end{array}$ & $\begin{array}{l}\text { Klyafetin çok } \\
\text { ilginç. }\end{array}$ & $\begin{array}{r}\text { Biz Irak'ta böyle } \\
\text { giyiniyoruz, nesi ilginç } \\
\text { anlamadım. }\end{array}$ \\
\hline
\end{tabular}

Yabancı bir ülkede çeşitli sebeplerden ötürü geçici ya da kalıcı olarak ikamet eden insanların çeşitli kültürel zorluklar yaşamaları kaçınılmazdır. Büyük bir kalabalığın içindeki diğer tüm azınlık grupları gibi onların da kasıtsız hakaretlerden muzdarip olmaları da muhtemeldir. İşte bu araştırma Türkiye'deki yabancıların bu çeşit kasıtsız hakaretlerin hangi türlerine ne oranda maruz kaldıklarının anlaşılması için yapılmıştır. 
Genel itibariyle görülen odur ki ülkemizde özellikle Arap ve Afrika kökenli yabancılara tahammül umulan seviyede değildir. Farklı kültürler hakkındaki eksik ve yanlış bilgiler sebebiyle zaman içerisinde birçok önyargı türemiş ve bunlar o toplumların ülkemizdeki fertlerine yansıtılır olmuştur. Sadece yabancı uyruklu oldukları için bu kişilere güzel sıfatlar yakıştırılamamaktadır. Ayrıca bu tür olumsuz tepkileri yaşayanlar okulda, iş hayatında ve sosyal hayatın hemen her alanında küçük görülmekte, ayrımcılığa maruz bırakılmakta ve dışlanmaktadırlar. Hatta çok üzücüdür ki Sue ve ekibinin (2007) sınıflandırmasında en ağır, en yaralayıcı grubu teşkil eden doğrudan ve kasıtlı saldırıların sıklığı araştırmamızda da göz ardı edilemeyecek seviyede gözlenmiştir. Özünde müşfik ve misafirperver olan Türk halkının farklı milletlerden insanlara karşı bu kadar tahammülsüz hale gelmiş olması şaşırtıcıdır.

\section{8. Öneriler}

Araştırmamızın ortaya çıkardığı sonuçlar konunun ciddiyetini göstermektedir. Dolayısıyla bu konu daha da fazla araştırılmalıdır. Sadece beş ilde gerçekleştirilen görüşmelerden elde edilen veriler ile ortaya çıkarılan çalışmamız bu hâliyle de anlamlı sonuçlar vermiş olmakla birlikte aynı konuda temsil yeteneği daha yüksek, daha kalabalık bir örneklemle yapılacak araştırmanın daha kapsamlı bilgiler vereceği aşikârdır.

Ülkemizde henüz çok yeni olan bu kavram ile ilgili daha fazla araştırmaya ihtiyaç duyulduğu görülmektedir. Bu yüzden bu konudaki çalışmaların sayısı artırılmalıdır. Hatta katılımcılar bölge bölge ve ülke ülke ayrımalı ve kimlere ne tür kasıtsız hakaretler yapıldığı tespit edilmelidir.

Aşağılama, küçük görme, ikinci sınıf vatandaş muamelesi ve doğrudan sözlü ve kasıtlı yapılan saldırıların varlığı ve çeşitliliği çok endișe vericidir. Türk halkının yabancılara karşı neden ve nasıl bu kadar olumsuz duygular beslemeye başladığı psiko-sosyal açıdan 
incelenmelidir.

Özellikle göçmenlerin muhatap oldukları resmî görevlilerin hatalı davranışları konusunda uyarılmaları ve doğru davranış şekilleri hususunda bilgilendirilmeleri gereklidir.

Sınıflarında ve okullarında göçmen çocuklar olan öğrenci ve öğretmenlere göçmenliğin ve zorluklarının anlatılması gereklidir. $\mathrm{Bu}$ çocukların belki de en çok beraber zaman geçirdikleri kişiler olan sınıf arkadaşları ve öğretmenlerinin onları anlamaya çalışmak konusunda daha gayretli olmaları, bu konuda bilgilendirilmeleri zaruridir.

Okullarda özellikle ilgili derslerin müfredatına mutlaka göçmenlik ile ilgili bir bölüm konulmalıdır.

İnsanların düşünce ve davranışlarında büyük etkisi olan sosyal medyanın ve basının maalesef bu konuda da halkımızı olumsuz etkilediği görülmektedir. Sosyal medyada cesaretlendirici paylaşımlara izin verilmemeli ve basının da ülkemizdeki yabancı uyrukluları hedef göstermesinin önüne geçilmelidir.

Kasitsız hakaret konusunu incelerken bu tür tutum ve davranışların ülkemizde sadece göçmenlere karşı olmadığını da söylemeliyiz. Çok önemli olduğunu düşündügümüz bir soru ile çalışmamızı bitirmek isteriz. Bu soruya verilecek cevap bizim eğitim sistemimizi şekillendirirken dikkat edeceğimiz hususları belirlemede önemli rol oynayacaktır.

Yukarıda sıralamaya çalıștığımız davranış örnekleri ülkemizde azınlıklar, etnik gruplar, mezhepler, bölgeler, farklı sosyal statüye sahip insanlar arasında da yaşanmakta mıdır? 


\section{Kaynakça}

Bonifacio, Luisa vd. "Microaggressions and Ethnic Identity in the Career Development of Latina College Students". The Counseling Psychologist, 46/4 (2018): 505-529.

Çınarbaş, D. C. vd. "Engelli mi Engellenen mi?: Türkiye'de Engellilerin Karşılaştıkları Ayrımcı Tavır ve Davranışlar". 17. Ulusal Psikoloji Kongresi :108-109. İstanbul: Boğaziçi Üniversitesi, 2012.

Durmuş, Mustafa. "Kültürlerin Karşılaşma Alanı Olarak Dil Öğretimi Süreçleri ve Mikro Saldırganlıklar". Milli Folklor, 122 (2019): 50-63.

Er, Mehmet. "Yabancı Dil Olarak Türkçe Öğretiminde Mikroagresyon". Uluslararası Yabancı Dil Olarak Türkçe Öğretimi Dergisi, 1/2 (2018): 92-99.

Garabayev, B. "Türkiye'de Yüksek Öğrenim Gören Türk Cumhuriyetleri Öğrencilerinin Uyum Sorunları ve Türkiye ve Türklere İlişkin Kalıp Yargılar". Niğde Üniversitesi, Yayımlanmamış yüksek lisans tezi. Niğde: Niğde Üniversitesi Sosyal Bilimler Enstitüsü.

Güleç, İsmail \& İnce, Bekir. "Türkçe Öğrenen Yabancıların Günlük Yaşama ilişkin Kültürel Algıları Üzerine Bir Araştırma". Sakarya University Journal of Education, 3/3 (2013): 95-106.

Hinton, Eric L. "Microinequities: When small slights lead to huge problems in the workplace". DiversityInc (Mart 2004)

Helms, Janet E. "A race is a nice thing to have: A guide to being a white person or understanding the white persons in your life. Topeka KS: Content Communications, (1992) 
Kıroğlu, Kasım vd. "Türkiye'de Öğrenim Gören Yabancı Uyruklu Lisans Öğrencilerinin Sosyo- Kültürel ve Ekonomik Sorunları". Mersin Üniversitesi Eğitim Fakültesi Dergisi, 6/2 (2010): 26-39.

Lilly, Flavius R. vd. "The Influence of Racial Microaggressions and Social Rank on Risk for Depression Among Minority Graduate and Professional Students". College Student journal, 52/1 (2018): 86-104.

McTernan, Emily. "Microaggressions, Equality, and Social Practices". Wiley Online Library, (2007).

Merriam-Webster Online Dictionary, https://www.merriamwebster.com/words-at-play/microaggression-words-werewatching (24.01.2019)

Merriam-Webster Sözlügüu, https://www.merriam-webster.com/ (12.12.2018).

Nigatu, H. Adane. 21 Racial Microaggressions You Hear on a Daily Basis (2013). www.buzzfeed.com. (12.12.2018)

Pierce, Chester. "Offensive Mechanisms". Black Seventees. Haz. Floyd Barbour. 265-266, 1970.

Shenoy-Packer, Suchitra. "Immigrant Professionals, Microaggressions, and Critical Sensemaking in the U.S. Workplace". Management Communication Quarterly, 29/2 (2015): 257-275.

Sue, Derald Wing vd. "Racial Microaggressions in Everyday Life: Implications for Clinical Practice". Teachers College, 62/4 (2007):271-286.

Ünal, Serdar. "Irksal Temelli Ayrımcılı̆̆ın Yeni Görünmez Yüzü: Kültürel Karşılaşmalar ve Mikro-Saldırganlıklar". Journal of 
Kasıtsız Hakaret (Microaggressions) ve Türkiye'de Sık Görülen Örnekleri

Social and Humanities Sciences Research, 5/28 (2018): 32883308.

Wells, Catharina. "Microaggressions: What They Are and Why They Matter." Texas Hispanic Journal of Law and Policy, 24/61 (2017) : 61-79.

Yüksek Öğretim Kurumu, https://istatistik.yok.gov.tr/ (05.01.2019).

Yurtdışı Türkler ve Akraba Topluluklar Başkanlığı, https://www.ytb.gov.tr/kurumsal/faaliyet-raporlari (20.01.2019).

Zukauskas, R., Salem Press Encyclopedia, www.salempress.com (25.12.2018) 
İsmail GÜLEÇ- Erkan ÖZDEN 